\title{
Pomorskie rzemiosła skórnicze w okresie przemian ustrojowych
} (XII-XIV wiek)

\section{Pomeranian leather working in the period of political transformation $\left(12^{\text {th }}-14^{\text {th }}\right.$ centuries $)$}

Zarys treści. W średniowiecznej wytwórczości skórzanej można wyróżnić kilka etapów, w których - na skutek oddziaływania różnych impulsów kulturowych - dokonywały się zasadnicze zmiany rzutujące na asortyment i jakość wytwarzanych produktów. Elementem najbardziej podatnym na innowacje technologiczne i estetyczne stroju było obuwie skórzane. Priorytetowe znaczenie dla rozwoju pomorskiego obuwnictwa miało wprowadzenie nowych elementów - odrębnej podeszwy, wstawek przedłużających okres użytkowania oraz ujednolicenie zabiegów wytwórczych i recepcja wzorców zachodnioeuropejskich.

Stowa kluczowe: Pomorze; średniowiecze; wytwórczość skórzana; obuwnictwo.

Przedmioty skórzane znajdowane w trakcie badań archeologicznych w ośrodkach miejskich liczone są niekiedy w tysiącach egzemplarzy. Paradoksalnie to właśnie masowość znalezisk sprawiła, że dopiero w ostatnich dekadach wytwórczość skórzana stała się przedmiotem badań w szerszym zakresie niż tylko określenia typologiczne i formalne wyrobów, przede wszystkim zaś obuwia. Dzięki zaawansowanym badaniom nad kolekcjami przedmiotów skórzanych i odpadów produkcyjnych z ośrodków rozlokowanych w pasie pobrzeża Bałtyku od Szczecina i Wolina po Gdańsk i Elbląg możemy dziś z dużym prawdopodobieństwem odtworzyć etapy kształtowania się rzemiosł skórzanych, głównie obuwnictwa, a także wskazać momenty przełomowe, w zasadniczy sposób wpływające na rozwój tej gałęzi wytwórczości od X do XV wieku. Osobnym problemem są uwarunkowania geograficzno-gospodarcze i kulturowo-społeczne, oddziaływujące na lokalne rynki zbytu, w tym także miejscowe tradycje i impulsy zewnętrzne. 
Pierwsze, do dzisiaj zresztą aktualne próby przedstawienia linii rozwojowej produktów szewskich $\mathrm{w}$ średniowieczu, przeprowadzone w oparciu o bogate materiały wykopaliskowe z Gdańska, podjął Henryk Wiklak (1960; 1969). Wprowadzona przez tego badacza podstawowa klasyfikacja tych wyrobów oraz ustalenia dotyczące technologii ich wytwarzania stosowane są nadal, sukcesywnie rozwijane i weryfikowane kolejnymi odkryciami, szczególnie intensywnie w ostatnich dwóch dekadach (Wywrot-Wyszkowska 2008; In gremio 2009; Kowalska 2010a; 2013a - tam szczegółowa literatura). W latach 60. ubiegłego wieku, równolegle $\mathrm{z}$ badaniami nad samymi produktami, podjęto także problematykę organizacji wytwórczości skórniczej w ośrodkach wczesnomiejskich i kwestie uzawodowienia pracy garbarzy i szewców, w tym wczesnego rozdzielenia się tych rzemiosł w odrębne dziedziny rzemieślnicze. W oparciu o źródła archeologiczne uznano, że we wczesnym średniowieczu istniały dziedziczne zawody, na długo przed powstaniem organizacji udokumentowanych w źródłach pisanych. Szczególnie ważne w tych rozważaniach okazały się studia Józefa Kaźmierczyka (1970), który podjął próbę oszacowania wielkości produkcji szewskiej we wczesnośredniowiecznym Wrocławiu na podstawie obliczeń powierzchni odpadów produkcyjnych. Poruszył też problem podziału prac w procesie wytwórczym, przyjmując funkcjonowanie wyspecjalizowanych pracowni w okresie przed powstaniem cechów, których statuty jednoznacznie określały zakres działania na poszczególnych etapach produkcji. Ten problem - przedcechowej organizacji wytwórczości szewskiej - ostatnio został omówiony na podstawie materiałów wykopaliskowych z Wolina (Kowalska 2006; 2013b) i Szczecina (Kowalska 2009; 2010a; 2012a).

Nie mniej istotne są rozważania na temat dystrybucji i sposobów zaopatrywania się w surowe skóry zwierzęce w okresie średniowiecza, przedstawione ostatnio na przykładzie źródeł z Kołobrzegu-Budzistowa i Szczecina, w oparciu o zaawansowane analizy zoologiczne (Wywrot-Wyszkowska, Radek 2007; Kowalska 2010a, s. 49 i nn.). Niezwykle istotnych informacji dla tych rozważań dostarczają analizy archeologiczne i zoologiczne odpadów i ścinków powstających na różnych etapach produkcji. Nie wystarcza określenie ,pracowni” jedynie na podstawie nagromadzenia odpadów w jednym miejscu, które w oczywisty sposób potwierdzają lokalną wzmożoną wytwórczość skórzaną. Ważna jest też ocena kształtu i jakości odpadów, pozwalająca na ustalenie sposobów dysponowania materiałem skórzanym i norm postępowania w procesie wytwórczym, co wiąże się również z określeniem asortymentu wyrobów (Wywrot-Wyszkowska 2008, s. 100-121; Kowalska 2010a, s. 49-59).

Badania nad średniowiecznym szewstwem pozwoliły na wyodrębnienie kilku typów konstrukcyjnych i stylistycznych obuwia. W XII-XIV wieku na Pomorzu właściwie nie było już wyrobów bezpośrednio wywodzących się z tradycji starożytnych (Wojtasik 1960; Hald 1972; Kowalska 2003)ํ. Trzeba jednak

${ }^{1}$ Tzw. chodaki, czyli obuwie uszyte z jednego płata skóry, przetrwały jedynie w modelach 
pamiętać, że w ośrodkach wczesnomiejskich zmiany gospodarcze dokonywały się szybciej niż w osiedlach typu wiejskiego, gdzie dłużej utrzymywał się autarkiczny charakter gospodarki. Jednym z najważniejszych etapów rozwoju obuwnictwa pomorskiego we wczesnym średniowieczu było przejście od form jednoczęściowych do wieloczęściowych, czyli złożonych z podeszwy i doszytego do niej wierzchu. Wprowadzenie odrębnej podeszwy dało początek przemianom obuwia, dokonującym się nie tylko w średniowieczu, ale trwającym właściwie do dziś. O ile jednak w najstarszych fazach średniowiecza najważniejszym motorem zmian były względy praktyczne, to już około XII wieku w ośrodkach pomorskich pojawiły się elementy świadczące o pewniejszym uwzględnianiu estetyki, a także o rozwarstwieniu społecznym manifestującym się ubiorem, którego obuwie było istotną częścią.

Wraz z dynamicznym upowszechnianiem się wyrobów wieloczęściowych równie szybko ugruntowały się nowe techniki szycia, pozwalające na ukrycie szwów wewnątrz obuwia, co powodowało nie tylko poprawę jego wyglądu, ale też wpływało na szczelność. Powtarzalność form, a przede wszystkim wyraźna standaryzacja zabiegów wytwórczych stały się przesłankami do wnioskowania o pojawieniu się wytwórczości zorganizowanej, zawodowej, a nawet o oddzieleniu się garbarstwa od szewstwa i rymarstwa (Kurnatowska 1983, s. 13). Moim zdaniem typowa wielokierunkowość zajęć uprawianych w ramach jednego gospodarstwa nie przesądza o możliwości istnienia w tym czasie odrębnego rzemiosła szewskiego, obsługującego anonimowych odbiorców. Niewątpliwy wpływ na rozwój szewstwa i zapewne pozostałych, pokrewnych dziedzin skórnictwa, miała sytuacja gospodarcza, a zwłaszcza powstanie rynków zbytu na wyroby rzemieślnicze. Praca „na zbyt” wymagała dostosowania zabiegów wytwórczych do potrzeb produkcji o pewnym stopniu umasowienia. Dość jednoznaczne w swej wymowie są zwłaszcza odkrycia pracowni skórzanych w Gdańsku (Wiklak 1988) oraz w wolińskiej dzielnicy Ogrody (Kowalska 2013a).

Do początków XII wieku zmiany w szewstwie dotyczyły głównie zróżnicowania stylistycznego obuwia, które wynikało z lokalnych potrzeb i upodobań. Od schyłku XI do połowy XII stulecia miały miejsce kolejne, dokonujące się skokowo zmiany, stanowiące o ,rewolucji” w obuwnictwie, w zasadniczy sposób wpływające na dalszy rozwój tej dziedziny wytwórczości. Mam na myśli bardzo szybkie upowszechnianie się rozmaitych dodatkowych elementów obuwia o charakterze konstrukcyjnym i estetycznym: podszywanych od strony wewnętrznej podkrążków chroniących miejsca wiązania i zapiętków wzmacniających tył cholewki (ryc. 1). Już pod koniec XII i w początkach XIII stulecia ich użycie stało się normą (Kowalska 2010a, s. 152). Powszechne stawały się lamówki - wąskie tasiemki skórzane otaczające górną krawędź wierzchu oraz uszczelki wszywane do wnętrza,

dziecięcych, inaczej niż u Słowian wschodnich, gdzie tzw. poršni cieszyły się dużą popularnością w okresie średniowiecza i nawet w czasach nowożytnych (Izjumova 1959; Kurbatov 2004; Osipov, Sobol 2013, ryc. 7:5; por. też Kowalska 2010a, przypis 136). 


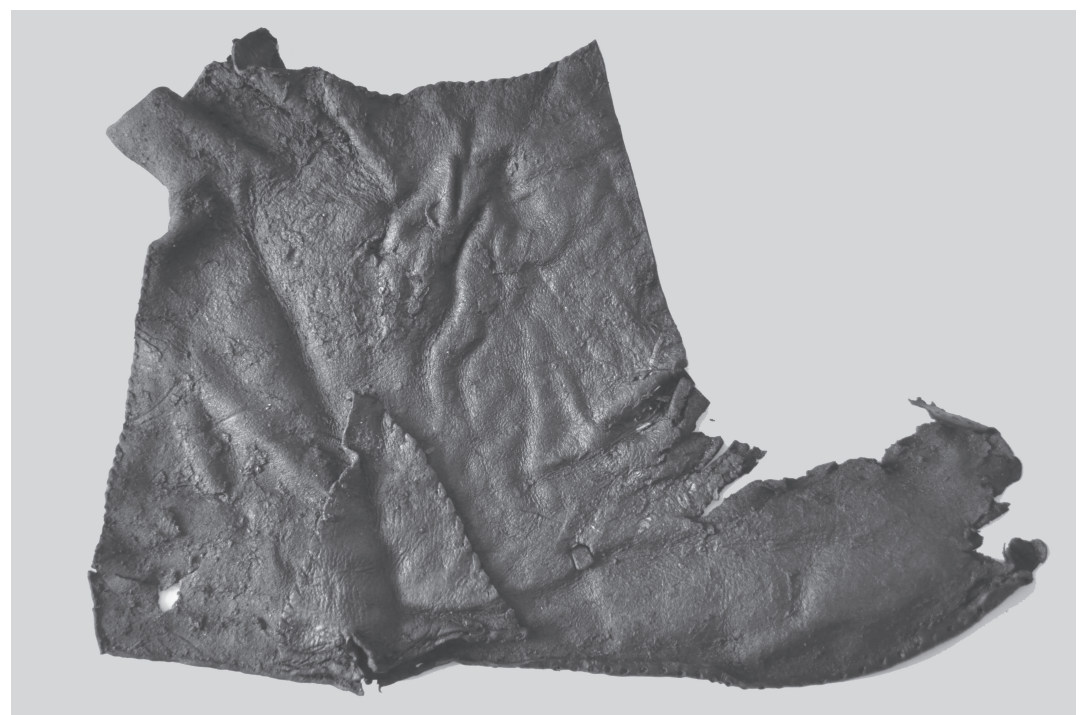

Ryc. 1. Białogard. Wierzch obuwia z trójkątnym zapiętkiem $z$ badań archeologicznych M. Dworaczyka (fot. A. B. Kowalska)

Fig. 1. Białogard. The upper part of a shoe with a triangular heel stiffener from the archaeological excavations of M. Dworaczyk (photo A. B. Kowalska)

pomiędzy wierzch a podeszwę, w celu lepszej izolacji przed przenikaniem do wnętrza wilgoci. Dzięki tym dodatkowym elementom znacznie wydłużył się okres użytkowania obuwia.

W 2. połowie XII-początkach XIII stulecia dominujące było obuwie z niską cholewką, sięgające kostki, mocowane na nodze tradycyjnym sposobem na jedno sznurowadło. Powszechniej występowały formy średniowysokie z cholewką zakrywającą kostkę i wystającą dość znacznie ponad nią. Dla schyłku wczesnego średniowiecza, około połowy XIII wieku, w wytwórczości szewskiej, oprócz różnorodności asortymentowej, dostrzec można wyraźne symptomy zmian jakościowych i estetycznych, świadczące o większym zróżnicowaniu społecznym konsumentów. Pojawiły się na przykład wierzchy bogato ornamentowane ażurem (ryc. 2), odnotowano także większą liczbę obuwia niewielkich rozmiarów - dziecięcego lub młodzieżowego.

Okres około połowy XIII wieku stanowi kolejną cezurę w wytwórczości obuwniczej. Ugruntowały się innowacje konstrukcyjne wprowadzone w XII stuleciu, natomiast zmianom podlegał wygląd i kształt poszczególnych elementów składowych obuwia. Wyraźne są na przykład różnice w sposobie profilowania podeszew - dość znacznie (w przypadku Szczecina o około 50\%) spadł udział łagodnie profilowanych, zgodnych z kształtem stopy podeszew na rzecz okazów o ostrzejszych kształtach, mocniej przewężonych w śródstopiu, z uwypuklonym 


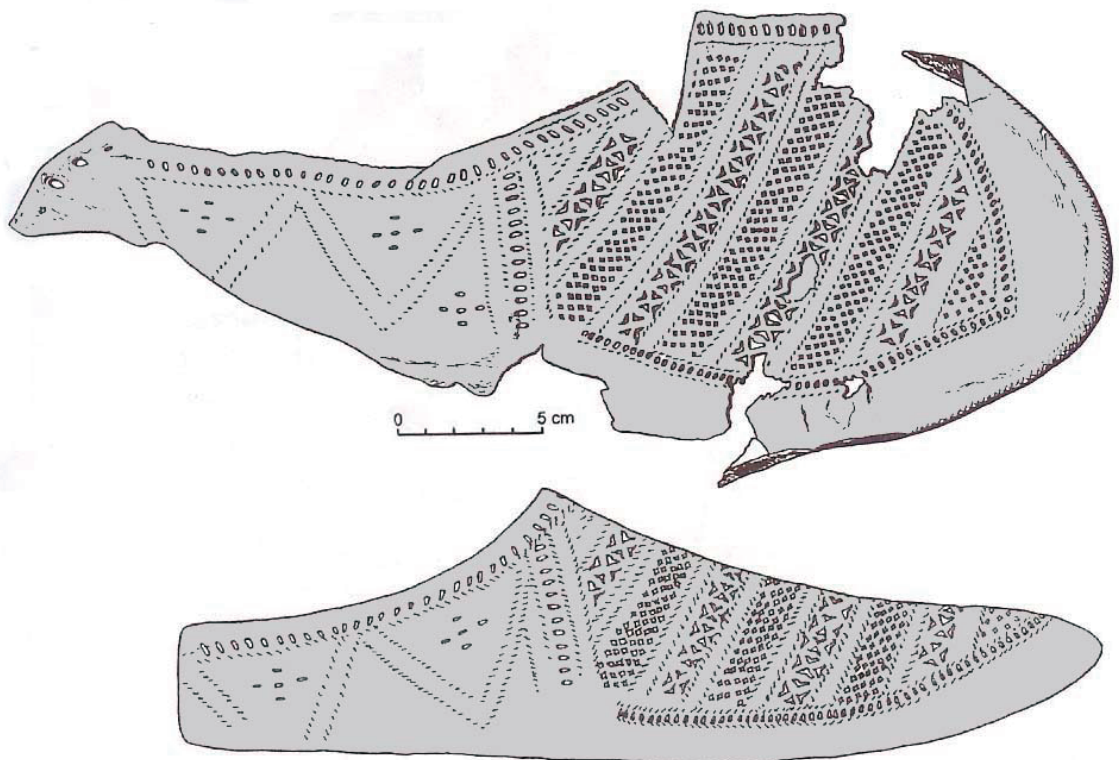

Ryc. 2. Szczecin-Podzamcze. Obuwie niskie zdobione ażurowaniem (rys. H. Bona) Fig. 2. Szczecin-Podzamcze. Low shoes decorated with openwork (drawing H. Bona)

przedstopiem. W XIII stuleciu, zwłaszcza zaś w jego 2. połowie, zmienił się kształt przednich części obuwia - z zaokrąglonych na korzyść spiczastych lub wręcz wydłużonych i ostro zakończonych (Wywrot-Wyszkowska 2008, ryc. 11; 2009, s. 142; 2010, s. 190 i nn.; Kowalska 2013a, s. 28-38). Zanik spodów z wyraźnie zaokrąglonym zakończeniem przedstopia odnotowano w zbiorach z około połowy XIV stulecia (ryc. 3). Podeszwy ze spiczastymi zakończeniami obrazują tendencję zmiany kształtu całej przedniej części obuwia z łagodnego na wyraźnie wydłużony, co należy łączyć $\mathrm{z}$ upowszechnieniem się mody gotyckiej. Z tym trendem wiąże się też wyraźnie smukłość podeszew, optycznie wydłużających obuwie, nadających im lekkości. Wszystkie te cechy: wysmuklenie, spiczaste lub ostre zakończenia i mocne profilowanie środkowej części są wyróżnikami szewstwa późniejszych faz średniowiecza.

Około połowy XIII wieku zaczęły pojawiać się podeszwy dzielone, złożone z dwóch lub rzadziej trzech części. W kolekcjach z większych ośrodków pomorskich (Kołobrzeg, Szczecin) ich odsetek sięgał 10\% (Wywrot-Wyszkowska 2008, s. 29-30; Kowalska 2013b, s. 35-36). W opinii badaczy stosowanie takich spodów wynikało przede wszystkim z potrzeby oszczędzania surowca (Schnack 1992, s. 52), istnieje też przekonanie, że stanowiły rodzaj napraw - do dobrych części doszywano kawałki innych, mniej zniszczonych podeszew (Schia 1977, s. 127-129; Goubitz, van Driel-Murray, Groenman-van Waateringe 2001, s. 76-77). Użycie 


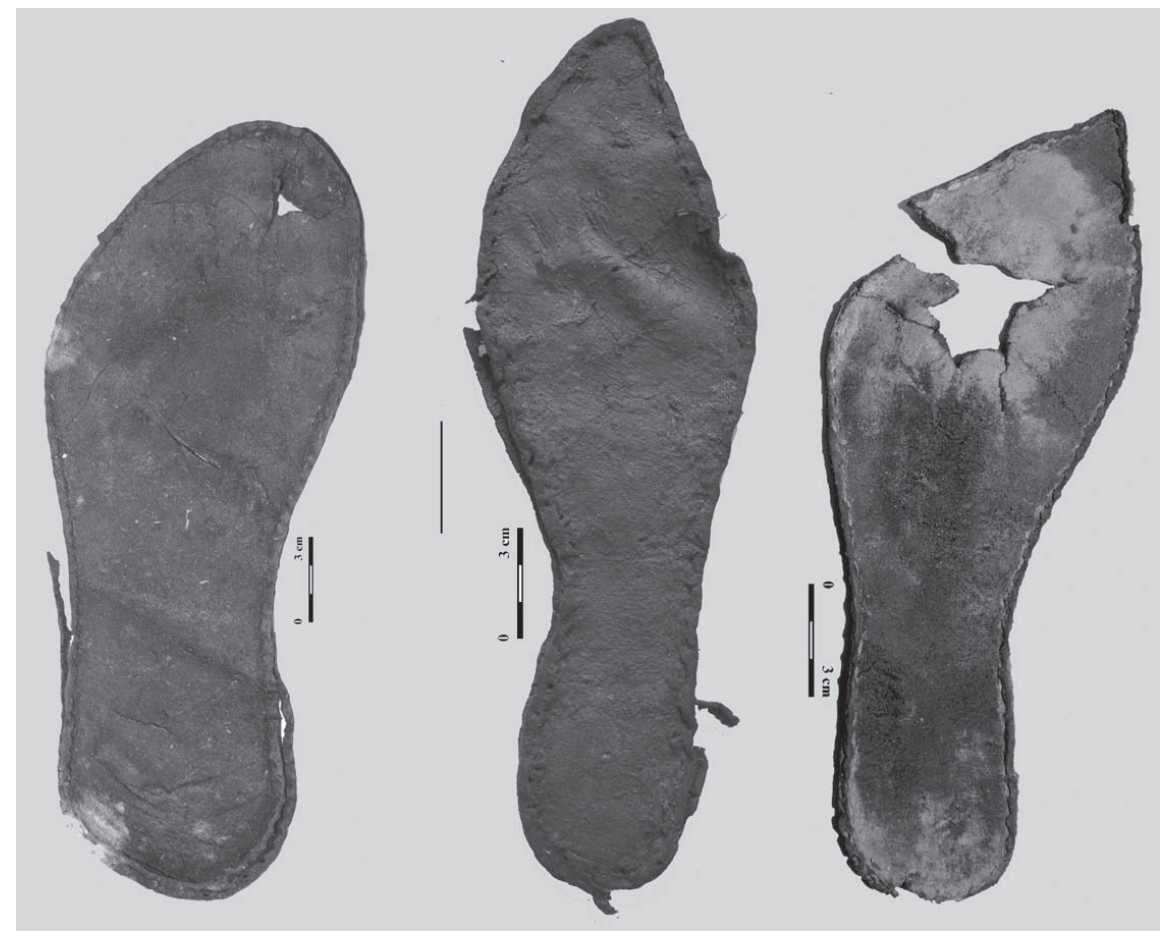

Ryc. 3. Różnie profilowane podeszwy z badań archeologicznych w Szczecinie i Białogardzie (fot. A. B. Kowalska)

Fig. 3. Variously shaped soles from archaeological excavations in Szczecin and Białogard (photo A. B. Kowalska)

spodów dzielonych (wieloczęściowych) uzasadnia też niedobór skór bydlęcych na Pomorzu w 1. połowie XIV stulecia, co zadaniem Beaty Wywrot-Wyszkowskiej powodowało konieczność maksymalnego wykorzystywania każdego kawałka skóry (Wywrot-Wyszkowska 2008, s. 29-30).

Obok oczywistych powodów racjonalnych, należy także brać pod uwagę inne przyczyny komponowania podeszew z dwóch lub trzech części, o czym świadczy ich identyczny odsetek w Kołobrzegu i Szczecinie oraz bardzo zbliżony w gdańskim porcie (Wywrot-Wyszkowska 2010, s. 195). W innych ośrodkach, na przykład w fińskim Turku, wystąpiły nielicznie w nawarstwieniach z XIV i XV wieku i zaliczone zostały do okazów o znacznej długości, wykrojonych z bardzo grubej skóry (Harjula 2008, s. 116-117). Spody złożone z kilku części są znane już z nawarstwień datowanych na wczesne średniowiecze (od XI wieku), odkrytych w Szlezwiku i Lubece (Schnack 1992, s. 51-52), a także w Oslo (Schia 1977, ryc. 15-16) i Lund (Cinthio 1976a, ryc. 287); wszędzie wiązały się z obuwiem dużych rozmiarów. Warto też dodać, że w Londynie były dużo bardziej 
powszechne niż w Skandynawii i północno-zachodniej Europie, zwłaszcza pod koniec XIV stulecia (Grew, de Neergaard 2001, s. 49). Moim zdaniem, niezależnie od pewnego dyskomfortu, jaki z pewnością towarzyszył użytkowaniu obuwia z dzieloną na kilka członów podeszwą, można przyjąć celowość tego zabiegu, zwłaszcza w przypadkach wycinania z grubej i sztywnej skóry bydlęcej. Miejsca zszycia zwiększały elastyczność podeszwy, ułatwiając tym samym chodzenie. Być może więc spody wieloczęściowe należałoby łączyć z obuwiem jakiegoś specjalnego przeznaczenia.

Zabiegiem o trudnej do wyjaśnienia funkcji, który łączy się w pewnym sensie z problemem wieloczęściowości, jest nacinanie części podeszwy w śródstopiu mniej więcej do połowy grubości skóry. W Szczecinie jeden taki okaz znaleziono w warstwie z 5. dekady XIII wieku, a pięć następnych (w tym dwa całe) w warstwach datowanych mniej precyzyjnie na późne średniowiecze, od 2. połowy XIII do połowy XIV wieku. Wydaje się, że nacinanie spodów także miało na celu zwiększenie ich giętkości, ułatwiającej stąpanie, podobnie jak w przypadku podeszew wieloczęściowych. Nie chodzi raczej o sygnowanie spodu, jak to ma miejsce w przypadku niektórych okazów nowożytnych (Osipov, Sobol 2013, ryc. 8).

Z kilkuczłonowymi spodami wiąże się używanie wkładek lub wyłożeń wyściełających wnętrze obuwia, chociaż ta uwaga dotyczy także podeszew jednoczęściowych. W szewstwie późnośredniowiecznym stosowano skórzane wyściółki korespondujące kształtem z podeszwami właściwymi, które zakrywały albo całą podeszwę, albo jedynie przedstopie lub tylko tylną część. Śródstopie nie wymagało dodatkowego wyłożenia, ponieważ nie stykało się bezpośrednio ze stopą (ze względu na krzywiznę podbicia). Analiza statystyczna materiałów kołobrzeskich dowiodła, że frekwencja spodów wieloczęściowych z dodatkowym wyłożeniem podnoszącym komfort użytkowania wzrasta w 2. połowie XIV stulecia (Wywrot-Wyszkowska 2008, s. 30). Najstarsze tego typu okazy kilkuwarstwowe, przynajmniej podwójne, znane są już od końca XI stulecia ze Skandynawii (Cinthio 1976b, s. 315). Nieliczne, bardzo zniszczone wyłożenia odkryto także w szczecińskich nawarstwieniach z okresu od 2. połowy XIII do XIV stulecia. Niekiedy rolę wyściółki pełniły inne materiały. Z badań ratowniczych w Pyrzycach znany jest przykład obuwia dużych rozmiarów, którego wnętrze wypełnione było słomą (Kowalska 1997). Rolę ocieplaczy pełniły też zapewne tkaniny lub owcze runo. Podeszwy wielowarstwowe, złożone z kilku warstw skóry o różnej grubości, i/lub izolacyjnej warstwy drewna albo kory były typowym elementem obuwia wczesnonowożytnego.

W późnym średniowieczu (w jego najmłodszych fazach) pojawiły się również elementy dodatkowe spodów obuwia, montowane od strony bezpośrednio stykającej się z podłożem, kształtem korespondujące z przedstopiem lub częścią tylną: zelówki i obcasy. Ich kształt i sposób montażu świadczą o tym, że wykonywane były celowo w trakcie produkcji nowego obuwia, nie zaś podczas naprawy 
zużytego spodu (Wywrot-Wyszkowska 2008, s. 37; 2010, s. 197). Niekiedy (np. w Kołobrzegu) przybijane były za pomocą metalowych ćwieków, stosowano też drewniane szpilki w rodzaju niewielkich kołeczków (np. w Turku) (Harjula 2008, fig. 86). Niezależnie od sposobu integracji ze spodem elementy te są zapowiedzią szewstwa renesansowego z XVI stulecia (Goubitz, van Driel-Murray, Groenman-van Waateringe 2001, s. 217). Wydaje się, że miejscem powstania tego nowego rozwiązania konstrukcyjnego jest Skandynawia. W Turku te zewnętrzne części podeszew datowane są na koniec XIV-1. połowy XV wieku. Podobną, stosunkowo wczesną metrykę mają tego typu znaleziska ze Sztokholmu i Lund. W szewstwie europejskim, poza Skandynawią, w tym także na Pomorzu, upowszechniły się dopiero od XVI stulecia (Harjula 2008, s. 119).

Warto jeszcze wspomnieć o uszczelkach (otokach) wstawianych pomiędzy wierzch a spód obuwia w celu uszczelnienia szwu. Ten rodzaj wstawek w szewstwie pomorskim wszedł w użycie już w 1. połowie XII wieku. Początkowo były to zwykłe płaskie paski skóry, z czasem pojawiły się uszczelki o trójkątnym przekroju, wykrojone z grubej i bardzo grubej skóry, wstawiane niczym klin między spód a wierzch, które w szewstwie późnośredniowiecznym wyparły niemal całkowicie okazy płaskie. Powszechność występowania strzępów otoków we wszystkich warstwach kulturowych, począwszy od XIII stulecia, pozwala stwierdzić, że uszczelnianie obuwia specjalnym kawałkiem skóry należało do kanonu rzemiosła szewskiego. W schyłkowych fazach późnego średniowiecza charakterystyczne były zwłaszcza uszczelki z przedniej części, powielające kształt przedstopia, z wyraźnie wydłużonym czubkiem wykraczającym poza podeszwę. Zastosowanie takiej wstawki, oprócz wymiaru praktycznego, miało też znaczenie estetyczne - optycznie wydłużało obuwie.

Zmiany w średniowiecznym obuwnictwie dotyczyły także wierzchów - sposobu rozkroju, liczby elementów, profilowania i dekoracji. Już w X stuleciu w wyższych warstwach społeczeństwa obuwie było dopełnieniem stroju reprezentacyjnego lub ceremonialnego (Turska 1987). Z badań archeologicznych w ośrodkach wczesnośredniowiecznych pochodzą okazy o wierzchach zdobionych haftem². Badacze są zgodni, że dekoracja podnosiła wartość tych wyrobów (Atkinson, Foreman 1992, s. 177-178), a tym samym także całego ubioru. Dowodzi też wyodrębniania się specjalizacji, bowiem była wykonywana już po wykroju z płata skóry, a przed zszyciem wszystkich elementów składowych (Schia 1977, s. 252). Na przykładzie tego elementu wczesnośredniowiecznego obuwia najlepiej

2 Por. na przykład obuwie z Hedeby (Groenman-van Waateringe 1984, ryc. 8:3), Lund (Blomqvist 1938, ryc. 15; Cinthio 1976a, ryc. 281: 1), Oslo (Schia 1977, ryc. 2, 4; 1987, ryc. 165: E), Ribe (Nielsen 1991, s. 94-96), Starej Ładogi (Kurbatov 1997, s. 119, ryc. 1), Elisenhof (GrenanderNyberg 1985, ryc. 74: 2), a także z Wysp Brytyjskich (Atkinson, Foreman 1992, ryc. 86) i ośrodków polskich: z Ostrowa Lednickiego (Drążkowska 2000, ryc. XLV: 1), Opola (Cehak-Hołubowiczowa 1954, s. 7-12; Hołubowicz 1956, s. 127-138), Szczecina (Kowalska 2012b) oraz Gdańska (Wiklak 1957, ryc. 1-3). 
uwidaczniają się różnice regionalne. Na terenach środkowo-wschodniej Słowiańszczyzny zaznacza się przewaga bogatych wątków wolutowych i kwietnych, podczas gdy w Europie Zachodniej i Północnej jest to częściej dekoracja geometryczna, zwłaszcza zaś linearna ${ }^{3}$. Pojedyncze znaleziska haftowanych wełnianymi nićmi przyszew szczecińskiego obuwia nawiązują do motywów zachodnioeuropejskich (Kowalska 2012b). Nie bez znaczenia dla charakteru dekoracji był także rodzaj surowca użytego do jej wykonania - nici wełnianych lub jedwabnych, albo metalowych drucików. W obuwnictwie wczesnośredniowiecznym spotyka się też niekiedy metalowe guzy lub ćwieki układane na przyszwach w różnych konfiguracjach (Striškiené 2007). Zdobione metalowymi aplikacjami obuwie śląskie z Wrocławia, Legnicy i Opola, a także pomorskie - z Gdańska, wydobyte z nawarstwień datowanych na XII-XIII stulecie, może wiązać się z odświętnym ubiorem bogatszych mieszkańców. Ten rodzaj zdobienia nie upowszechnił się jednak na Pomorzu Zachodnim. Warto też zauważyć, że użytkownicy rozmaicie dekorowanego obuwia niekoniecznie musieli rekrutować się z różnych warstw społecznych. Wyroby wykwintniejsze mogły być uzupełnieniem odświętnego ubioru nawet uboższej ludności, zwłaszcza w schyłkowych fazach funkcjonowania ośrodków wczesnośredniowiecznych, w których odnotowano znaczne zróżnicowanie stylistyczne wyrobów szewskich (Kowalska 2010a, wykres 15). Warto wspomnieć, że znaczenie haftu i ornamentyki w żywych kolorach zwiększyło się w tradycyjnym ubiorze romańskim, na który - zdaniem historyków mody - oddziaływały wpływy bizantyjskie (Boucher 2004, s. 134-135).

W czasach transformacji prawnej, ustrojowej i gospodarczej większość ośrodków charakteryzowała dążność do racjonalizacji rozkroju i tym samym minimalizacji odpadów produkcyjnych a tym samym do oszczędności surowca. Zasadniczo takie same pod względem konstrukcyjnym wierzchy obuwia różniły się między sobą wysokością cholewki, kształtem wstawek konstrukcyjnych i uzupełniających, sposobem mocowania na nodze, szerokością otworu wzuwalnego, dekoracją i innymi pomniejszymi cechami (ryc. 4). Wydaje się, że wielorakość rozwiązań o znaczeniu niekonstrukcyjnym wynikała z dopasowywania uniwersalnych wzorników stosowanych w większości pracowni do potrzeb indywidualnych odbiorców. Niezależnie od sposobu organizacji produkcji, w wytwórczości obuwniczej XII-XIV wieku obserwuje się wprowadzanie kolejnych udoskonaleń, polegających głównie na lepszym umocowaniu obuwia na nodze i dopasowaniu do kształtu stopy, a także zmiany wynikające z przyjmowania określonej mody, zwłaszcza wśród wyższych warstw społecznych. Dosyć wyraźnie, zwłaszcza w 2. połowie XIII-XIV wieku, zaznacza się podział na obuwie codzienne czy robocze oraz o podwyższonych walorach estetycznych, które z pewnością można wiązać z ubiorem odświętnym. W tym czasie bardzo wyraźnie zaznacza się

${ }^{3}$ Ostatnio uwagi na temat zdobienia obuwia skórzanego - por. Konczewska 2011 - tam przegląd literatury. 

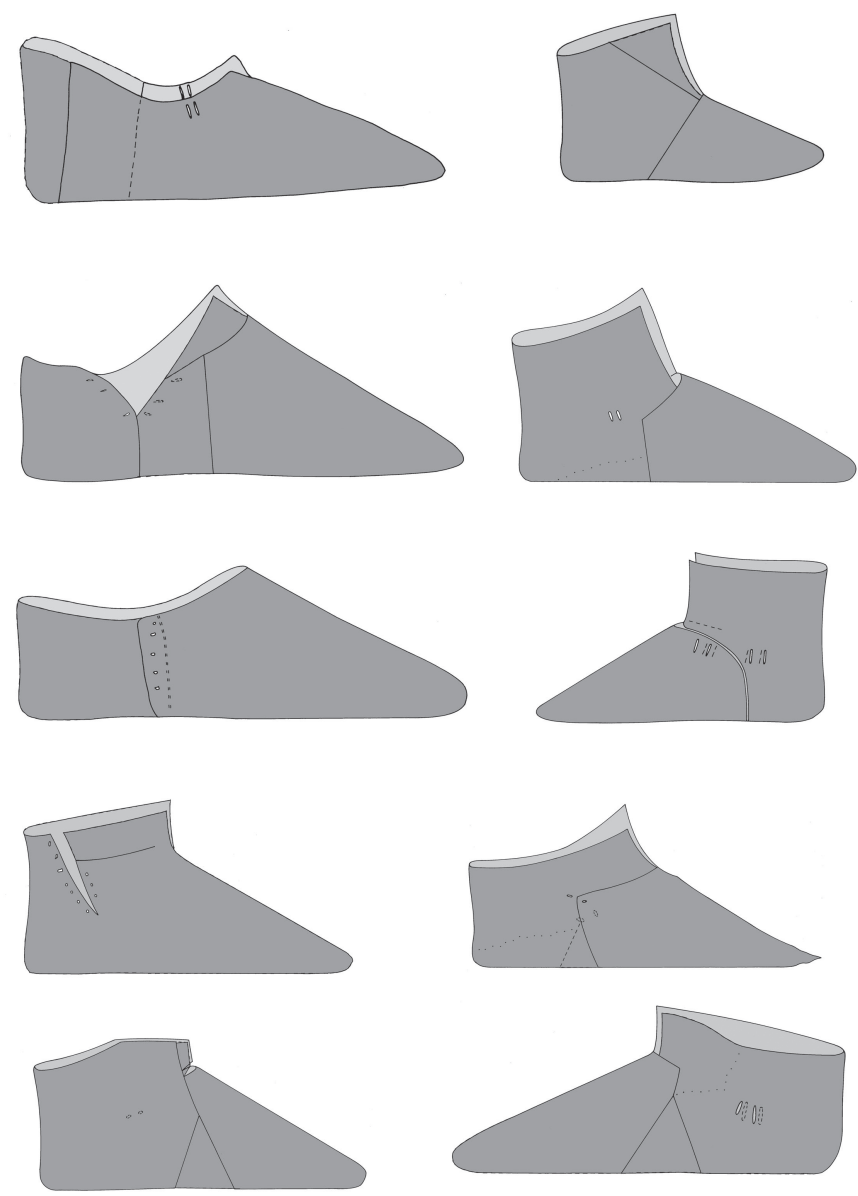

Ryc. 4. Szczecin-Podzamcze. Różne formy i typy obuwia późnośredniowiecznego (oprac. A. B. Kowalska)

Fig. 4. Szczecin-Podzamcze. Various forms and types of late medieval shoes (prepared by A. B. Kowalska)

wzrost liczby obuwia niewielkich rozmiarów - dziecięcego oraz znajdujacego się $\mathrm{w}$ przedziale wielkościowym między rozmiarami dziecięcymi a damskimi. Charakterystycznym zjawiskiem jest także pojawienie się form dla dzieci, wytwarzanych według tych samych kanonów co wyroby dla dorosłych.

Wydaje się, że przynajmniej część zmian dokonujących się w pomorskim obuwnictwie w XII stuleciu, zwłaszcza zaś w jego 2. połowie, można wiązać $\mathrm{z}$ recepcją wzorców mody zachodnioeuropejskiej. Moda, jako nowe zjawisko kulturowe, wcześnie docierała na ziemie położone w granicach dzisiejszej Polski (Możdżyńska-Nawotka 2005, s. 10). W obuwiu tej doby zaznaczyła się 
tendencja do wyraźnego podkreślania smukłości poprzez wydłużenie części przedniej, czasem dodatkowo akcentowanej ozdobnym haftem lub aplikacją (Kowalska 2010a, tab. 10; 2013b, ryc. 75). Pod koniec XII wieku wyraźnie nasiliło się występowanie obuwia wydłużonego i smukłego, co mogło wiązać się z noszeniem długiej odzieży, spod której wystawały jedynie czubki. Uwaga ta dotyczy ubioru warstw zamożniejszych, bowiem ten użytkowany przez ludność uboższą był krótki i pozostawał praktycznie niezmieniony do końca średniowiecza. Wzrost liczebności wspomnianego wyżej obuwia można zatem uznać za przejaw ogólnego wzrostu dobrobytu. Zmiany w ubiorze około połowy XII wieku zwiastowały narodziny mody w znaczeniu, jakie znamy dzisiaj. Ich istotą było ogólnie wydłużenie odzieży, które upowszechniło się dzięki kontaktom Europejczyków ze światem arabskim w okresie wypraw krzyżowych. W pomorskich materiałach archeologicznych reminiscencje tych zjawisk odnotowano już w 2. połowie XII wieku. W wyraźnie dominującej grupie obuwia codziennego dostrzec można elementy wykraczające ponad przeciętność. Tak przynajmniej tłumaczę obecność haftowanych lamówek, pierwotnie najpewniej kolorowych, które intensywnie wystąpiły w krótkim przedziale czasowym (ostatnia dekada XII wieku) na terenie dzielnicy nadodrzańskiej w Szczecinie (Kowalska 2010, s. 98). Nawiązują one do romańskiego ubioru zachodnioeuropejskiego, do strojów o charakterze reprezentacyjnym (Kowalska 2012b, s. 314-315).

Ukształtowane w XII stuleciu kanony ubioru i stroju przetrwały blisko dwa i pół stulecia, do około połowy XIV wieku (Boucher 2004, s. 151). Na południowe wybrzeże Morza Bałtyckiego res novae docierały stosunkowo szybko, chociaż wyraźniejsze ożywienie można zaobserwować w XIII i 1. połowie XIV wieku. Trzeba też mieć na uwadze stosunkowo wczesne wprowadzanie w miastach regulacji dotyczących rodzaju, kształtu, rozmiaru i dekoracyjności poszczególnych elementów ubioru, w tym kołnierzy, nakryć, głowy, biżuterii, galanterii, a także nosków obuwia (Możdżyńska-Nawotka 2005, s. 21, 151). Być może reakcją na te obostrzenia był odnotowany w ogólnej charakterystyce XIII-wiecznych ubiorów zanik starannego wykończenia szat i pozbawienie ich zdobności (Gutkowska-Rychlewska 1968, s. 139). Szczególnie dobrze tendencję tę ilustrują znaleziska obuwia ze Szczecina, które w tym czasie straciło cechy pewnej finezyjności na rzecz obuwia prostego, wyraźnie dostosowanego do potrzeb codzienności, inaczej niż w przypadku wyrobów szewskich odkrytych w Gdańsku i Kołobrzegu. Należy jednak zwrócić uwagę, że przywołane w tym miejscu wyroby szczecińskie pochodzą z rejonu uważanego za najbiedniejszy w obrębie średniowiecznego miasta (Kowalska 2013b). W Kołobrzegu tego typu obuwie smukłe w materiałach z 2. połowy XIV wieku stanowiło blisko 90\% (Wywrot-Wyszkowska 2008, s. 60), w Szczecinie ich odsetek nie przekracza 30\%, nawet jeśli uwzględnimy charakterystyczne spiczasto zakończone uszczelki, „wydłużające” podeszwę i tym samym całe obuwie. Wydaje się, że „dziobate” egzemplarze można łączyć 
z zamożniejszymi mieszczanami, co potwierdzają także nieliczne pomorskie źródła ikonograficzne. Zarówno w Kołobrzegu, jak i Szczecinie nie znaleziono dotąd obuwia przesadnie, nienaturalnie wydłużonego, które wiąże się z ubiorem dostojników świeckich i kościelnych (Groenman-van Waateringe, Velt 1975, s. 106 i nn.; Wywrot-Wyszkowska 2008, s. 60-61). W Polsce znane jest ono z badań późnośredniowiecznych zamków (Milewska 1977, ryc. 3), w Europie Zachodniej ze znaczących centrów politycznych i kościelnych (Grew, Neergaard de 1988). Obuwie z wąskimi, uniesionymi ku górze noskami, tzw. poulaine, występowały w Europie już w XIII wieku, ale szczególne znaczenie zyskały na przełomie XIV i XV wieku oraz po raz drugi pod koniec XV stulecia. Nie ma - jak dotąd - zgodności, co do ich proweniencji. Niektórzy badacze skłonni są wiązać je z Polską (Swann 2001, s. 65-66), jednak większość wywodzi tę formę ze Wschodu (Możdżyńska-Nawotka 2005, s. 16).

Średniowieczna wytwórczość skórzana nie ograniczała się oczywiście jedynie do obuwia. W materiałach wykopaliskowych trudno jednak doszukać się wyrobów kuśnierskich i elementów stroju wykonanych z cienkich skór licowych - płaszczy, kapturów, nogawic, nakryć głowy czy kaftanów. Obecność skór kuśnierskich potwierdzają w przy padku znalezisk archeologicznych jedynie analizy zoologiczne. Wyroby wykonane ze skór licowych to najczęściej pasy, różnego rodzaju pokrowce i torby, czasem rękawice i dające się zidentyfikować elementy uzbrojenia. Chyba najwyraźniejsze zmiany między wczesnym a późnym średniowieczem odnotowano w przypadku skórzanych pochewek. Około połowy XIII stulecia zaczęły pojawiać się egzemplarze zaopatrzone w specyficzne żelazne okucia z długimi wąsami, które szybko wyparły tradycyjne okucia z metali kolorowych. Wyraźnie upowszechniła się także moda na dekorowanie brzegów pochewek poprzez wycinanie kształtów geometrycznych na krawędziach ich dolnych części (ryc. 5). Z dużą ostrożnością można zasygnalizować związek takiego sposobu zdobienia z tzw. stylem niemieckim w modzie późnośredniowiecznej. W ten sposób wycinano skraje sukien, kołnierze kapturów i krawędzie czepców (Boucher 2004, s. 174). Być może profilowanie w podobny sposób brzegów pochewek jest naśladownictwem nawiązującym do tej mody. Najmniejsza zmienność stylistyczna dotyczy sakiewek. We wczesnym średniowieczu używano wyrobów o zaokrąglonych dnach, złożonych z dwóch zszytych ze sobą części i ściągniętych rzemykiem. Egzemplarze późniejsze zawsze zrobione są z jednego kawałka skóry zszytego na bokach; nawiązują tym samym do tekstylnych jałmużniczek.

Podsumowując należy stwierdzić, że zmiany uwidaczniające się w stylistyce pomorskich wyrobów skórzanych w 2. połowie XIII-1. połowy XIV stulecia mogą wynikać z norm ujętych w statutach cechowych, ściśle regulujących zakres wykonywanych czynności i jakość produktów. Z pewnością sprzyjało to unifikacji odzieży i dodatków skórzanych. Nieliczne elementy ekskluzywne, wykraczające poza przeciętność, sugerują zróżnicowanie majątkowe i społeczne mieszczan, co 

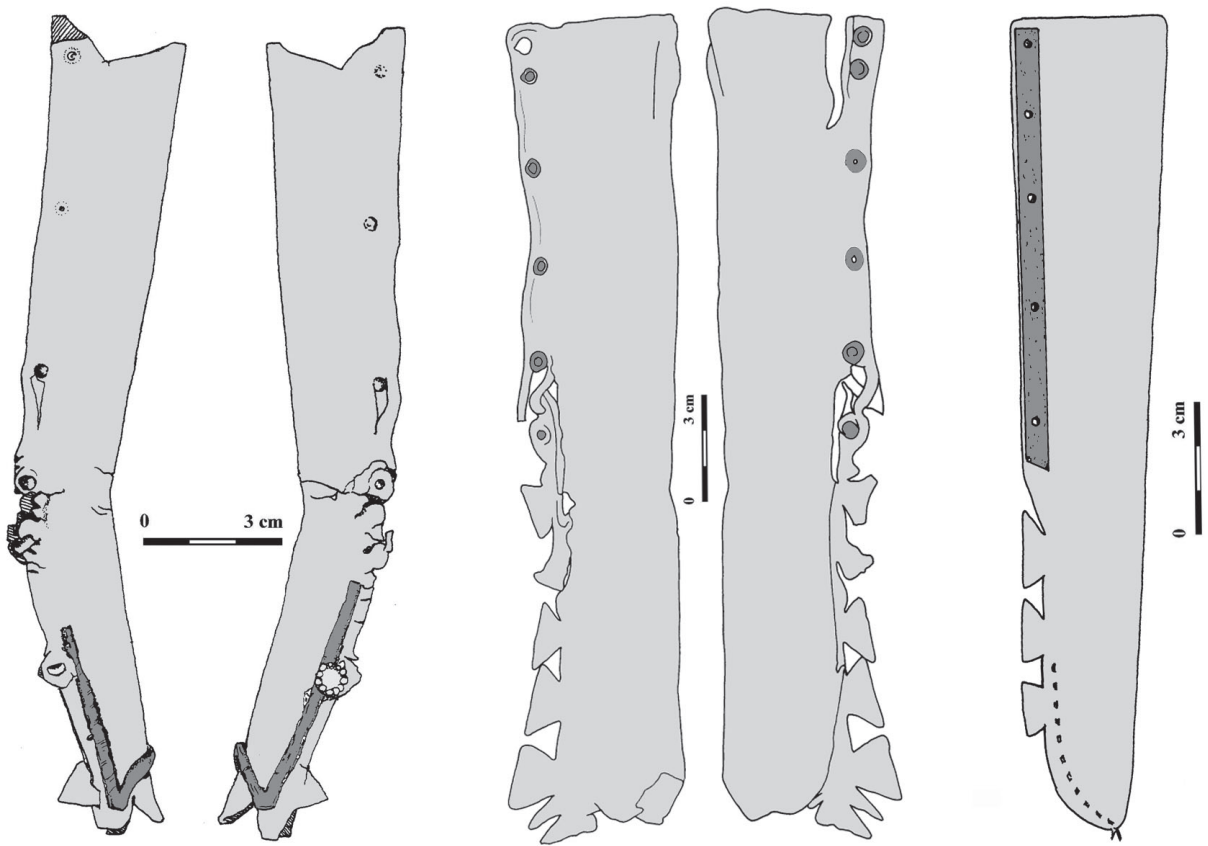

Ryc. 5. Szczecin-Podzamcze. Pochewki późnośredniowieczne (oprac. A. B. Kowalska) Fig. 5. Szczecin-Podzamcze. Late medieval sheaths (prepared by A. B. Kowalska)

znajduje też potwierdzenie w skromnej ikonografii pomorskiej, a także znacznie szerzej - zachodnioeuropejskiej.

\section{Literatura}

Atkinson D., Foreman M.

1992 The leather, [w:] Excavations at 33-35 Eastgate, Beverly 1983-86, red. P. Armstrong, D. Evans, D. G. Tomlinson, Sheffield Excavation Reports 3, Sheffield, s. 175-187.

Blomquvist R.

1938 Medeltida skor i Lund. Fynden från kvarteret Apotekaren nr 5, Kulturen 1938 (1939), s. 189-219.

Boucher F.

2004 Historia mody. Dzieje ubiorów od czasów prehistorycznych do końca XX wieku, Warszawa.

Cehak-Hołubowiczowa $\mathrm{H}$.

1954 Trzewiki opolskie, Dawna Kultura, R. 1, s. 7-13. 
Cinthio M.

1976a Garveri-och skomakerihantering. Uppgrävt förflutet för PK-banekn i Lund. En investering $i$ arkeologi, Archaeologia Lundensia 7, s. 215-218.

1976b Skor, Uppgrävt förlutet för PK-banken i Lund, red. A. W. Mårtensson, Archaeologia Lundensia 7, s. 307-316.

Drążkowska A.

2000 Wyroby skórzane, [w:] Wczesnośredniowieczne mosty przy Ostrowie Lednickim, t. 1: Mosty traktu gnieźnieńskiego, red. Z. Kurnatowska, Lednica-Toruń, s. 189-199.

Goubitz O., van Driel-Murray C., Groenman-van Waateringe W.

2001 Stepping through the Time. Archaeological Footwear from Prehistoric Times until 1800, Zwolle.

Grenander-Nyberg G.

1985 Die Lederfunde aus der frühgeschichtlichen Wurt Elisenhof, [w:] Die Lederfunde... Studien zur Küstenarchäologie Schelzwig-Holsteins, Serie A Elisenhof,

t. 5, Frankfurt am Mein-Bern-New York, s. 220-251.

Grew F., Neergaard de M.

2001 Shoes and pattens, Medieval finds from excavations in London 2, wyd. 2, London.

Groenman-van Waateringe W.

1984 Die Lederfunde von Haithabu, Berichte über die Ausgrabungen in Haithabu, z. 21, Neumünster.

Groenman-van Waateringe W., Velt L. M.

1975 Schuhmode im späten Mittelalter. Funde und Abbildungen, Zeitschrift für Archäologie des Mittelalters, R. 3, s. 95-119.

Gutkowska-Rychlewska M.

1968 Historia ubiorów, Wrocław.

Hald M.

1972 Primitive Shoes. An Archeological-Ethnological Study Based upon Shoe Finds from the Jutland Peninsula, Publications of the National Museum of Denmark Archeological-Historical Series 1, t. 13, Copenhagen.

Harjula J.

2008 Before the heels. Footwear and shoemaking in Turku in the Middle Ages and Hołubowicz W. the beginning of the early modern period, Turku.

1956 Opole $w$ wiekach $X-X I I$, Katowice.

In gremio

2009 In gremio - in praxi. Studia nad średniowiecznym skórnictwem, red. A. B. Kowalska, B. Wywrot-Wyszkowska, Szczecin.

Izjumova S. A.

1959 K istorii koževennogo i sapožnogo remesl Novgoroda Velikogo, Materialy i Issledovaniâ po Arheologii SSSR, nr 65/2, s. 193-222

Kaźmierczyk J.

1970 Wrocław lewobrzeżny we wczesnym średniowieczu, t. 2, Wrocław. 
Konczewska M.

2011 Obuwie zdobione w średniowiecznym Wrocławiu, Śląskie Sprawozdania Archeologiczne, t. 53, s. 259-282.

Kowalska A. B.

1997 Późnośredniowieczne zabytki skórzane z Pyrzyc, Materiały Zachodniopomorskie, t. 42, s. 219-272.

2003 Poczatki rzemiosła szewskiego we wczesnośredniowiecznym Wolinie, [w:] Res et fontes, red. T. Galiński, E. Wilgocki, Szczecin, s. 159-170.

2006 Uwagi na temat wytwórczości szewskiej w Wolinie i Szczecinie w VIII-X wieku, [w:] Świat Słowian wczesnego średniowiecza, red. M. Dworaczyk $\mathrm{i}$ in., Szczecin-Wrocław, s. 197-209.

2009 Dom szewca, czy szewc w domu?, [w:] Ad Oderam fluwium. Księga dedykowana pamięci Edwarda Dąbrowskiego, red. B. Gruszka, Zielona Góra, s. 529-536.

2010 Wytwórczość skórzana we wczesnośredniowiecznym Szczecinie, Szczecin.

2012a Uwagi na temat haftów na wczesnośredniowiecznym obuwiu skórzanym ze Szczecina, [w:] Z najdawniejszych dziejów. Grzegorzowi Domańskiemu na pięćdziesięciolecie pracy naukowej, red. A. Jaszewska, Zielona Góra, s. 313-319.

2012b From a homemade product to guild production - the development of leather production in the Early Medieval Szczecin, [w:] Transformationen und Umbrüche des 12./13. Jahrhunderts: Beiträge der Sektion zur slawischen Frühgeschichte der 19. Jahrestagung des Mittel-und Ostdeutschen Verbandes für Altertumnsforschung in Görlitz, 01. bis 03. März 2010, Beiträge zur Urund Fürgeschichte Mitteleuropas 64, s. 139-144.

2013a Rzemiosło szewskie wczesnośredniowiecznego Wolina, [w:] Wolin wczesnośredniowieczny, red. B. Stanisławski, W. Filipowiak, Origines Polonorum, t. 6, cz. 1, Warszawa, s. 201-235.

2013b Wytwórczość skórzana w późnośredniowiecznej Dzielnicy Chyżyńskiej w Szczecinie, Szczecin.

Kurbatov A. V.

1997 Rannesrednevekovaâ obuv Povolhov'â $i$ voprosy složeniâ gorodskogo pemesla, [w:] Drevnosti Povolhov'â, red. F. Biermann, T. Kersting, A. Klemmt, T. Westphalen, St. Petersburg, s. 117-128.

2004 Koževennoje proizvodstvo Tveri XIII-XV vv, S-Peterburg.

Kurnatowska Z.

1983 Rozwój problematyki badawczej warcheologii wczesnego średniowiecza w Polsce, Slavia Antiqua, t. 29, s. 1-21.

Milewska M.

1977 Dokumentacja archeologiczna znalezisk obuwia późnośredniowiecznego. Propozycja metody, Kwartalnik Historii Kultury Materialnej, R. 35, nr 4, s. 529-542.

Możdżyńska-Nawotka M.

2005 O modach $i$ strojach, Wrocław. 
Nielsen I.

1991 The leather finds, [w:] Ribe excavations 1970-76, t. 3, red. M. Bencard, L. B. Jørgensen, H. B. Madsen, Esbejrg, s. 79-98.

Osipov D. O., Sobol'V. E.

2013 Kollekciâ kožanoj obuvi iz raskopokv Smolenske, Materiały Zachodniopomorskie, Nowa Seria, t. 9, s. 371-401.

Schia E.

1977 Sko som arkeologisk kildemateriale, Hikuin, t. 3, 304-324.

1987 Sko og Støvler, De arkeologiske utravninger i Gamlebyen, t. 3, Søndre felt, Oslo, s. 329-412.

Schnack Ch.

1992 Die mittelalterlichen Schuhe aus Schleswig, [w:] Ausgrabungen in Schleswig, Berichte und Studien, t. 10, Neumünster.

Striškiené E.

2007 Diržiu kapinynas žiemgaliu kultūros kontekse Ir unikalūs VIII-IX a. radinai, Archaeologia Lituana, t. 8, s. 117-126.

Swann J.

2001 History of footwear in Norway, Sweden and Finland. Prehistory to 1950, Stockholm.

Turska K.

1987 Ubiór dworski w Polsce $w$ dobie pierwszych Jagiellonów, Wrocław.

Wiklak H.

1957 Obuwie dawnych gdańszczan, Z otchłani wieków, R. 23, z. 2, s. 78-85.

1960 Obuwie gdańskie z X-XIII w., [w:] Gdańsk Wczesnośredniowieczny, t. 3, red. J. Kamińska, Gdańsk.

1969 Polskie obuwie wczesnośredniowieczne z VIII-XIII w. na podstawie wykopalisk, Materiały Wczesnośredniowieczne, t. 6, s. 475-516.

1988 Wczesnośredniowieczne pracownie szewskie na Pomorzu Gdańskim, Pomorania Antiqua, t. 13, s. 161-170.

Wojtasik J.

1960 Wczesnośredniowieczne wyroby ze skóry znalezione na stanowisku 4 w Wolinie, Materiały Zachodniopomorskie, t. 6, 159-208.

Wywrot-Wyszkowska B.

2008 Skórnictwo w lokacyjnym Kołobrzegu. XIII-XV wiek, Szczecin.

2009 Uwagi na temat wytwórczości obuwniczej w późnośredniowiecznym Kołobrzegu, Archaeologia Historica Polona, t. 18, s. 141-167.

2010 Zabytki skórzane odkryte w obrębie późnośredniowiecznego portu gdańskiego, Archeologia Gdańska, t. 4, s. 189-223.

Wywrot-Wyszkowska B., Radek T.

2007 Obróbka skóry, [w:] Kołobrzeg. Wczesne miasto nad Battykiem, red. L. Leciejewicz, M. Rębkowski, Warszawa, s. 215-240. 


\section{POMERANIAN LEATHER WORKING IN THE PERIOD OF POLITICAL TRANSFORMATION $\left(12^{\text {TH }}-14^{\text {TH }}\right.$ CENTURIES)}

Summary

Research on medieval shoemaking allowed for the identification of several structural and stylistic types of Pomeranian footwear. In the $12^{\text {th }}-14^{\text {th }}$ century in Pomerania there were no products actually directly derived from ancient traditions. One of the most important stages of this type of production in the Early Middle Ages was the transition from single-piece footwear to complex forms with the soles and upper parts sewn together. Along with the dynamic widespread use of multi-piece products, new sewing techniques allowing the maker to hide the stitches inside the footwear also quickly developed. It not only improved the footwear's appearance, but also it made it more impermeable to water. The typical varied nature of activities carried out within a single household does not rule out the existence of a separate shoemaking craft supplying customers. From the late $11^{\text {th }}$ to the mid- $12^{\text {th }}$ century changes occurred that significantly influenced the further development of this branch of production. A variety of additional footwear elements of both construction and aesthetic nature quickly became popular. In the late $12^{\text {th }}$ and early $13^{\text {th }}$ century it had already become the norm to stitch binding on the inside of a shoe lace hole to protect it from wear and to use a heel stiffener to strengthen the back of the quarter. In the second half of the $12^{\text {th }}$-early $13^{\text {th }}$ century the dominant form was footwear with a low, ankle-high quarter, fastened by a single shoelace. Mid-high products of a quarter covering the ankle and extending over it became more common. In the mid- $13^{\text {th }}$ century, apart from the diversity of the product range, clear signs of quality and aesthetic changes are evident. They are evidence of a larger social diversity amongst consumers. About the mid- $13^{\text {th }}$ century the design innovations introduced in the $12^{\text {th }}$ century were consolidated, while the look and shape of individual components of footwear was changeable. The features of shoemaking in the later stages of the Middle Ages were slender, pointed, strongly profiled soles. There are also soles composed of two or three parts as well as more multi-layered ones. In the youngest stages of the Middle Ages additional elements on the bottoms of shoes were noted: outsoles and heels. Their shape and manner of fastening is evidence that they were made deliberately during the production of new footwear and not during its repair. Essentially the same in terms of the design, the shoe uppers differed in quarter height, shape and design and complementary inserts, the manner of fastening, the width of the opening of the shoe, decoration and other minor features. Quite clearly, especially in the second half of the $13^{\text {th }}-14^{\text {th }}$ century, there was a division between everyday or working footwear and the enhanced aesthetic value that can be associated with festive attire. At this time the number of children's shoes produced also significantly increased. At least some part of the changes taking place in Pomeranian shoemaking in the $12^{\text {th }}$ century, especially in its second half, can be associated with the adoption of Western fashion patterns. The canons of costume formed in this century survived for nearly two and a half centuries, until about the mid- $14^{\text {th }}$ century.

Medieval leather working was not limited to footwear. In materials from excavations it is difficult, however, to detect furriers' products and costume elements made of thin grain leather (cloaks, hoods, leggings, headdress or robes). The presence of furrier products in the case of archaeological finds is confirmed only by zoological analyses. 
Products made from grain leather are mainly belts, various cases and bags, gloves, and sometimes identifiable parts of weaponry. The most evident differences between leather products from the early and the late Middle Ages are the sheaths. About the mid- $13^{\text {th }}$ century specimens with specific iron fittings with a long ferrule began to appear. They soon replaced traditional fittings of non-ferrous metals. The fashion for decorating the sheaths' edges by cutting geometric patterns into their lower parts became popular. The smallest stylistic variability is evident in pouches.

To the southern coast of the Baltic Sea res novae arrived relatively quickly, although a more noticeable boom took place in the $13^{\text {th }}$ century and the first half of the $14^{\text {th }}$ century. Changes perceptible in the style of Pomeranian leather products in the second half of the $13^{\text {th }}$-first half of the $14^{\text {th }}$ century may result from the standards included in guild statutes, strictly regulating the scope of activities and quality of products. 